\title{
EVERYDAY MEALS ETIQUETTE IN FOOD CULTURE OF URBAN TATARS-MUSLIMS
}

\author{
Nadezhda Rychkova \\ Kazan National Research Technological University, Russia \\ e-mail:nadvas2@rambler.ru
}

\begin{abstract}
The article views the religious aspects of food etiquette of Kazan Tatars based on the polling results, statistical data, and literature sources. The topicality of the issue is due to its poor coverage; it is actualised by the religious renaissance of the Tatars in the post-Soviet period, the dramatically increased interest in the genealogical roots of their ethnic culture, factors of its development and structure of self-identification. The authors compare the bases of nutritional behaviour of the Tatars with the recommendations stipulated by the Islamic sources, and disclose the degree of their compliance with the canons. The research revealed both the competencies (knowledge of the Islamic etiquette rules) and the level of their actual occurrence. For comparison, the similar results were taken, obtained during the research of a Tajik community in Kazan - a group with stronger expressed religious characteristics, compared to the Tatars. The research revealed the variety of the canonic Islamic food culture by the example of two Muslim models (Tatar and Tajik), both in terms of individual nutrition components (main foods, national cuisine, ways of cooking, etc.), and in terms of food culture in general, including etiquette.
\end{abstract}

Keywords: etiquette, food culture, Muslims, Tatars 


\section{Introduction}

Among the numerous components of ethnic culture, a special role is played by the elements constituting the life-support system, i.e., the constituents without which human life becomes extremely complicated or impossible at all. Such components, alongside economic forms, labour tools, dwelling, clothes and some others, include food with the whole complex of objects and processes related to it. Food as an element of culture has come a long historical path, constantly becoming more complicated and acquiring various forms. As an indispensable element for maintaining life, food has acquired sustainable forms reflecting the ethnic specificity of human collectives. It appeared to be the least prone to levelling, unification and, finally, globalisation - the objective processes emphasising the unity of the human race. In the culture of each people on Earth, their own cuisine has been formed, with its peculiar traditions and features, which, as it seems, are doomed for long-term existence. Simultaneously, etiquette was being formed - a code of rules shaping people's behaviour during cooking and taking meals. The etiquette, in turn, was influenced by a whole range of factors - economic, social, historical-cultural, due to which the behaviour rules acquired the stable features of the regional and ethnic specificity.

Studying food and nutritional behaviour of people has always been topical. It is topical today, too, taking into account the dynamic character of modern life, the numerous transformations, the active cultural interactions and mutual influences - everything which characterises the development of ethnic cultures.

The article presents the experience of studying food etiquette by the example of the Tatars - one of the largest ethnic groups in the Russian Federation. The research is based on literature and statistical sources, as well as authors' materials and observations obtained during the implementation of a scientific project "Religious determinants in food culture (by the example of the Tatars and Tajiks of Kazan)" (2016-2017). The main tool was polling of the respondents. The sample size was 300 people and it included urban Tatars - Muslims. The sample structure by gender, age, and main social groups corresponds to the general population structure.

The diverse scientific literature devoted to the research of food and food etiquette, both in Russia and abroad, can be grouped into three main areas: natural scientific, ethnographic and sociological. The natural scientific approach is aimed at the issues of food safety, bases of healthy nutrition (Maddahi et al. 
2014; Nading 2017). The sociological approach is determined by dynamic social transformations in the society, polarisation of the global community into "the satiated" and "the hungry", which sets new scientific tasks of studying the actual problems of life of individuals (Veselov 2015; Veselov 2016; Scott 2001). The ethnographic approach is related to viewing food as ethnocultural phenomenon possessing distinct ethno-differentiating and ethno-integrating properties, which arouses great researcher interest around the world (Traditsionnaya pischa 2001; Etnografija pitanija 1981; Renner 2007). We use the complex ethno-sociological approach which, alongside apparent accent on the ethnocultural constituent, pays much attention to the social aspects of the issue, and uses sociological methods.

The research of food and food etiquette of the Volga Tatars has its own history. The first significant data on the issue were left in the $19^{\text {th }}$ century by Karl Fuks (Fuks 1991) and Kayum Nasyri (Nasyri 2015). This basis allowed a deeper study of the issue, which resulted in a comprehensive article by $\mathrm{K}$. and M. Gubaydullins: "Food of the Kazan Tatars" (Gubaydullin \& Gubaydullina 1927), and a section titled "Food" in a monograph by N. I. Vorobyev: "Material culture of the Kazan Tatars. Experience of ethnographic research" (Vorobyev 1930). Both works are peculiar for the detailed description of food and valuable remarks on etiquette characteristic of the Tatars of the end of the $19^{\text {th }}$ and the first third of the $20^{\text {th }}$ centuries. Later publications devoted to the Tatars' food, both summarising fundamental monographs (Tatars 1967; Muhamedova 1972; Tatars 2001) and individual articles (Gabdrafikova 2013; Gatina-Shafikova 2016; Nurmukhametova 2013), did not contribute much, except some facts from little-known sources or materials of field research of the authors. Therefore, the specific research of the Tatar food and food etiquette, including those with comparative quantitative materials, remain much demanded.

\section{Confessional Composition of the Urban Tatars}

The ancestors of the Volga Tatars adopted Islam over one thousand years ago. Since then, the Islamic tradition in the Middle Volga region has been much transformed (Gayazov). This process was influenced most by the Kazan Khanate annexation to the Russian state (middle of the $16^{\text {th }}$ century) and the territorial location of the Tatars within the zone of Christian-Muslim borderline and intense contacts with their Finnish-speaking and Slavonic-speaking neigh- 
bours. The popularity of a reformatory bourgeois-liberal nationalistic movement (Jadidism) among the Volga Tatars in the 1880s-1890s determined the features which distinguish the local Islam from other, first of all radical, trends. A significant influence was made by the fact that after the 1917 October Revolution the Tatars found themselves in the epicentre of social upheaval, including mass atheisation of the population. By the second half of the $20^{\text {th }}$ century, the prevalence of religious beliefs among the population decreased sharply: by the end of the 1960s, the share of believers among the Kazan Tatars was $25.8 \%$, by the end of the 1980s - not more than 30\% (Kildeev 2014: 135). In general, by the beginning of the 1990s, among the Tatars in Tatarstan there were $17.9 \%$ of believers, $19.7 \%$ of the hesitant, $46.6 \%$ of the indifferent, and $15.8 \%$ of the atheists (Kildeev 2014: 141). The next period of the social life liberalisation influenced the increased level of religious beliefs among the population. The dynamics of the urban Tatars, considering themselves to be believers of various degrees, was as follows: $1990-34 \%$; $1994-66 \%$; $1997-81 \%$ (41\% of them called themselves rather believers than non-believers) (Musina 2011:329).

At the present stage of religious renaissance, the Tatar culture comprises both the secular and the religious tradition, forming a rather sophisticated picture of the ethnic mode of living. As shown by the 2011 research, about $84 \%$ of urban Tatars considered themselves to be believers, among which the shares of "active" and "passive" believers are approximately equal (Musina 2011: 329). Among the Tatar youth, over $80 \%$ considered themselves to be believers, but the ratio of those who observe the rituals and those who do not was 11 to 70 (Khodzhaeva 2013: 298). The research of 2013 showed that $84.3 \%$ of the urban Tatar respondents considered themselves to be believers, over a half of which (about 56\%) were "practising" believers (those who try to observe the religious traditions and rituals); the rest considered themselves to be "nominal" believers (those who do not observe the traditions and rituals) (Musina 2016: 22). However, this statistics is based exclusively on the self-identification of the respondents and does not take into account the actual religious practices. In general, the recent researches mark the stabilisation of the number people self-identifying themselves as believers, but the share of practising believers among them grows.

Our research, in compliance with its objectives, comprised only the religiously devout respondents. 


\section{Bases of Islamic Food Etiquette}

As is known, the Quran and other Islamic sources contain the detailed list of behaviour norms regulating almost all spheres of life of the Muslims. The Islamic food etiquette is also described in detail (Etiket 2018). It is based on the conception that food and nutrition process do not just satisfy the human vital needs (material aspects), but have a hidden intrinsic spiritual meaning. In the Islamic culture, food is the source of nutrition and the source of pleasureas well as the source of health; both a therapeutic means and a means of improving and elevation of a human. The significance of food in Islam is emphasised by the fact that food and nutrition are mentioned in a large number of the Quran surahs (over 250 ayats).

Based on the Islamic recommendations concerning food, one may classify the etiquette norms into groups, taking into account the sequence of the process (preparing for a meal; a meal per se; finishing a meal) or its features (everyday or festive meal; absence or presence of guests, etc.). In each group, the rules of behaviour will be distinctly lined up according to their topicality - the necessity and possibility to apply them in the specific community at the given period of time. The Islamic etiquette rules are of various characters: they may be categorical or voluntary, prohibitive or resolving; they may pursue hygienic or health-improving and therapeutic purposes; they may contain religious dogmas requiring either rigorous observance, or conscious implementation, etc.

Thus, for example, the hygienic meaning apparently prevails in the recommendation to wash hands before and after a meal. Such norms as praising the God at the beginning and the end of a meal, or declining an invitation for a meal containing prohibited objects, do not require any explanations, they just must be observed. While the requirement that before a meal the person should realise that they take food to maintain their body for worshipping the God, implies abstracting from the taste, visual and other hedonistic aspects and concentrating on the idea that this food would help to fulfil the religious duties. As for such recommendations as to eat on a cloth laid on the floor, or to take food with three fingers, they conform to the accepted behaviour rules only in certain societies.

The Islamic sources pay significant attention to the principles of healthy nutrition. These, in particular, include moderation in eating. Some Islamic preachers believed that food is the main cause of all diseases and the habit of 
satiation is the cause of all ailments. They identified the reverse link between eating and bodily health, considering that everyone who starts eating more, starts being sick more often. Thus, several rules of healthy nutrition were formulated to preserve good health: start eating in a positive mood; do not sit at the table if you are not hungry; stop the meal while you are still hungry; chew the food thoroughly; give preference to natural products, etc. Apparently, these principles are universal and inherent not only for Muslim cultures; it is enough to recall, for example, the condemnation of gluttony as one of the deadly sins in Christianity.

A number of recommendations in Islam are of expressed social character. Thus, people are encouraged to help the hungry, the poor and the needy; the value of any, even small, source and amount of food is stated; arrogance and demonstration of excess extravagance in treating guests is impeached, as well as preferring of the rich and high-born table companions to the ordinary ones. Also, Islam establishes the principles of tolerant relations with the believers of other confessions, allowing common meals.

An important feature of most Islamic etiquette norms is that the sources do not explain them, giving broad scope for free interpretation of these norms by the followers. Our results, as shown below, demonstrate that Muslim actively use these opportunities when following the Islamic norms in accordance with their conceptions, preferences and tastes.

\section{Norms of Nutrition Behaviour of the Tatars}

The fundamental regulating principle in Islam is the distinction between the permissible (halal) and the forbidden (haram). In the nutrition etiquette, this principle is directly related to a number of norms; some of these norms were studied in our project. Generally, the respondents are not only familiar well enough with the terms "halal" ( $72 \%$ of respondents) and "haram" (68\% of respondents), but the majority of them ( $68.5 \%$ of all respondents) claimed that they try to observe these rules in nutrition.

At the same time, as our research showed, declarations sometimes diverge with the actual behaviour when observing specific requirements. For example, a well-known prohibition in Islam refers to drinking alcohol; it is forbidden not only to drink alcohol, but even to be present at the meal where it is served. According to the poll results, the Tatars do not always observe this rule. Of all 
the respondents, less than a half (42\%) agree with this norm, 30\% do not agree with it, $28 \%$ could not answer. By comparison, $97.8 \%$ of the Tajik respondents in Kazan agreed with this norm. The second question from the category of prohibition norms referred to the negative attitude of Islam towards using silver and golden kitchenware for eating and drinking. Among the polled Tatars, this prohibition is accepted as a norm only by $22.4 \%$ men and $14 \%$ women; about $40 \%$ of respondents could not define their attitude to this norm; one fifth of the respondents accept the prohibition in full; the same amount mostly accept it. Comparing these answers to those of the Tajiks, we see that they differ greatly: $96 \%$ of the Tajiks accept the prohibition to use the kitchenware made of precious metals for eating and drinking.

The same group of questions included two indicators of accepting and executing a number of religious dogmas. One of them referred to beginning a meal with commemoration of Allah and thanking Him after a meal. According to the poll, $31.3 \%$ of the respondents always observe this norm, $18.5 \%$ do it frequently. Over a third of the respondents $(36.4 \%)$ do it from time to time. In their comments these respondents, as a rule, stated that they observe this norm during collective meals at religious festivals and rituals. Apparently, this norm is not stereotyped for them; it is not a part of their religious conscience, but is executed as a pattern of collective behaviour. This norm is never observed by $8.5 \%$ of the respondents ( $11 \%$ men and about $7 \%$ women). It should be reminded that all our respondents consider themselves to be Muslim believers in a varying degree. In the reference group of the Tajiks the above norm is considered to be mandatory: $100 \%$ of the respondents told that they observe it.

The second indicator in this group of questions was an answer to the question: "Do you consider eating with the left hand or with two fingers a deed of Shaitan?" One third of the Tatar respondents had difficulty answering this question. As for the rest, about $40 \%$ of the respondents agree with it, about $30 \%$ do not agree. There were no significant differences in this indicator in various age-gender groups of the Tatars. In the Tajik group, the number of those who agree with the above statement is close to $80 \%$.

The above norms are close to the recommendation of Islam not to reject an invitation for a joint meal with the representatives of other Abrahamic religions (Christianity and Judaism). Over $80 \%$ of the Tatar respondents agreed with that norm; $12 \%$ are indifferent regarding this situation; $7.6 \%$ do not agree. The opinion of the Kazan Tajiks in this sphere is significantly different: less than half 
of the respondents agree with it (44\%), others are against. Supposedly, these results are due to the fact that the Tatars are more ready for interethnic and interconfessional contacts than the Tajiks. While the Kazan Tajiks are more oriented towards communication with their congeners (Stolyarova \& Maddahi 2012), the Tatars, who have been living next to the Russian and other Volga peoples - Christians and pagans - for over 400 years, have elaborated the forms of peaceful interaction with them in all spheres of life - family, friends, neighbours, working. It is not accidental that answering the question about a joint meal with the Christians and Jews our Tatar respondents added a comment: "With pleasure!"

Several questions were related to the Islamic norms of healthcare character. The simplest norm of washing hands before a meal is observed by the majority of our respondents: $81.7 \%$ of the respondents always wash their hands $(71.9 \%$ men and $89.5 \%$ women); $14.1 \%$ do it often ( $23.4 \%$ men and $6.8 \%$ women). An absolute majority of these people see only hygienic sense in the procedure of washing hands; about 3\% associate this action with the norms of Islam; about $20 \%$ see the double sense - both religious ("this is prescribed in the Quran") and hygienic.

Among the rules of healthy eating, Islam specifically supports moderation in eating and thorough chewing of food. Our research showed that many neglect these recommendations. Thus, $68 \%$ of the Tatar respondents admitted they eat too much, while over a half (56.2\%) said they eat while not hungry. Only $4 \%$ of the respondents are not prone to gastronomic excessiveness; $12 \%$ sometimes over-eat. The behaviour of men and women in our data collection is identical. It should be noted that the corresponding indicators among the Tajiks are significantly lower: $28 \%$ of the respondents admitted they eat too much; $24 \%$ said they eat while not hungry.

Thorough chewing of food, recommended both by religion and dietology, is not a stereotyped behaviour for most of the respondents. Over half of the respondents (55\%) admitted that they have a habit of eating quickly. Only about $13 \%$ of the Tatar respondents do not have such a habit; another $18 \%$ do not generally do that. Notably, this is one of the few questions in which the indicators of the Tatars and the Tajiks coincide (57\% of the Tajik respondents make haste while eating).

The next block of questions referred to the norms of social character. Two conjugate questions: "Do you consider treating other people with food to be 
a piety deed?" and "If you spot a hungry person while eating, do you invite them to share the meal?" provided a lot of positive answers among the Tatar respondents $-86 \%$ and $81 \%$ respectively (among the Tajiks, $100 \%$ of the respondents gave positive answers to both questions). As for the Islamic call not to make differences between the healthy and the disabled people when choosing one's table companions, over $60 \%$ of the Tatar respondents agreed with it; $18 \%$ of the respondents do not make any difference as for this issue. In this situation, men are less punctilious than women, though the difference is statistically not significant. However, compared to the Tajiks, $99 \%$ of whom support this Islamic norm, the Tatars look more exacting. The difference is also significant as for the Islamic recommendation to abstain from a meal intended for rich people only. While $92 \%$ of the Tajik respondents support this norm, only $33 \%$ of the Tatar respondents do. About $30 \%$ of the Tatars completely disagree with this norm, while for the majority (about $40 \%$ ) this is not important.

From the viewpoint of Islam, collective meals should be preferred - the food towards which many hands are stretched. For the Tajiks, this norm is almost mandatory, $98 \%$ of the respondents observe it. For the Tatars, the situation is not as unambiguous, though there are not very many opponents of collective meals $-14 \%$ of the respondents. The rest are divided into approximately equal parts: one half of the respondents prefer collective meals to individual ones, the other half is indifferent. The motifs of behaviour differ depending on the preferences. The advocates of individual meals explain their choice by inconveniences occurring during collective meals: "I'm shy", "I don't like conversations", "I don't like being watched", etc. The advocates of collective meals speak of their personal preferences ("It is more fun together", "It is more interesting", "Communication is pleasant", etc.), adding religious motifs: "A collective meal is a piety", "Sunnah prescribes it", "There is more Baraka (goodness)", etc.

\section{Conclusion}

Thus, the etiquette related to nutrition behaviour of the Tatars undoubtedly bears the features of the traditional cultural complex formed under the strong influence of the Islamic factor. However, the declared behaviour norms do not always coincide with the actual forms of behaviour, as our research showed. Actually, one may speak of the specific Muslim variant of the Islamic food culture canon, inherent to the urban Tatars. This variant reflects several features 
of the Tatars: a combination of the ethnic and confessional forms of identity (the form of the so called folk Islam in Tatars); unpopularity of the radical (fundamental) Islam; close historical links with the representatives of other ethnoses and confessions. Thus said, the Tatars perceive themselves as a part of the Islamic world and try to highlight their unity with it by various means, including the food culture and etiquette as its indispensable part.

\section{Acknowledgements}

The article is prepared with the financial support of the Russian Foundation for Basic Research, project No. 16-01-00285 "Religious determinants in a culture of food (on example of the Tatars and the Tajiks of Kazan)".

\section{References}

Fuks, Karl 1991 [1844]. Kazanskie tataryi v statisticheskom i etnograficheskom otnosheniiyakh [Kazan Tatars in Statistical and Ethnographic Relations]. Reprint Edition. Kazan: Fond of TYAK.

Gabdrafikova, Liliya 2013. Kultura pitaniya gorodskikh tatar (konets XIX - nachalo $X X v$.) [Culture of Nutrition of Urban Tatars (Late XIX - Early XX Century)]. Etnograficheskoe obozrenie, No. 2, pp. 138-149.

Gatina-Shafikova, Dina 2016. Kukhnya tatarskogo naroda: istoriya i sovremennost [Kitchen of the Tatar People: History and Modernity], 1. Real'noe vremja, 30.11.2016. Available at https://realnoevremya.ru/articles/49509, last accessed on 11.01.2018.

Gayazov, Lenar 2015. Osobennosti tatarskogo tradicionnogo islama v postsovetskij period [Features of Tatar Traditional Islam in the Post-Soviet Period]. Islamovedenie, No. 2, pp. 86-94.

Gubaydullin, Kadur \& Gubaydullina, Marjam 1927. Pischa kazanskikh tatar [Food of the Kazan Tatars]. Kazan.

Etiket 2018 = Etiket prinjatija pishchi po islamu [Etiquette of Eating in Islam]. The Center of Researches of the Qu'ran and Sunnah Republic of Tatarstan. Available at http://quran-sunna.ru/etiket-pishhi-po-islamu, last accessed on 21.01.2018.

Etnografija pitanija narodov stran zarubezhnoj Azii: Opyt sravnitel'noj tipologii 1981. [Ethnography of Nutrition of Peoples of Countries of Foreign Asia: Experience of Comparative Typology]. Moscow: Nauka. 
Khodjaeva, Ekaterina 2013. Religioznost musulmanskoy molodeji v perspektive kolichestvennogo i kachestvennogo issledovaniya [Religiousness of Muslim youth in the perspective of quantitative and qualitative research]. In: R. N. Musina \& G. F. Gabdrakhmanova \& G. I. Makarova \& L. V. Sagitova (eds.) Etnosotsiologiya $v$ Tatarstane: opyt polevykh issledovaniy [Ethnosociology in Tatarstan: The Experience of Field Research]. Sbornik statey k yubileyu Leokadii Mihaylovnyi Drobijevoy. Kazan: The Institute of History named by Sh. Mardjani, Academy of Sciencies, Republic of Tatarstan, pp. 171-183.

Kildeev, Mansur 2014. Uroven' musul'manskoj religioznosti naselenija v Srednem Povolzh'e i Priural'e po dannym sovetskih sociologicheskih issledovanij (19661991) [The Level of Muslim Religiosity Population in the Middle Volga and the Urals According to Soviet Sociological Research (1966-1991)]. Gosudarstvo. Religija. Cerkov', No. 1 (32), pp. 131-150.

Maddahi, Javad \& Haidary, Abbas \& Stolyarova, Guzel 2014. Food as an Element of the Scapegoat. The Anthropologist. International Journal of Contemporary and Applied Studies of Man, Vol. 18 (3), pp. 847-857.

Muhamedova, Ramziya 1972. Tatary-mishari. Istoriko-etnograficheskoe issledovanie [The Tatars-Mishars. Historical and Ethnographic Research]. Moscow: Nauka.

Musina, Rozalinda 2011. Etnokonfessionalnyie protsessyi v gorodakh RT: tendentsii razvitiya v postsovetskiy period [Ethno-Confessional Processes in the Cities of the Republic of Tatarstan: Development Trends in the Post-Soviet Period]. Etnologicheskie issledovaniya $v$ Tatarstane V. Kazan: Yaz; The Institute of History named by Sh. Mardjani, Academy of Sciencies, Republic of Tatarstan, pp. 326-346.

Musina, Rozalinda 2016. Identichnost' tatar v uslovijakh religioznogo vozrozhdenija $\mathrm{v}$ sovremennom Tatarstane [Identity of the Tatars in Conditions of Religious Revival in Modern Tatarstan]. Islam i tjurkskij mir: problemy jazyka, literatury, istorii i religii. Materialy Mezhdunarodnoj tjurkologicheskoj konferencii (Rossija, Respublika Tatarstan, g. Elabuga, 22. aprelja 2016 g.). Kazan: University of Kazan Press, pp. 22-24.

Nading, Alex 2017. Orientation and Crafted Bureaucracy: Finding Dignity in Nicaraguan Food Safety. American Anthropologist, 119 (3), pp. 478-490.

Nasyri, Kayum 2015. Nastavleniya povaru [Instructions to the Cook]. "Sokrovishchnica Tatarstana”. Posvjashchaetsja 190-letiju Kajuma Nasyri i 20-letiju Instituta ekonomiki, upravlenija i prava (g. Kazan). Kazan: Poznanie.

Nurmuhametova, Raushanija 2013. Razvitie kulinarnoy leksiki tatarskogo yazyka XX nachala XXI veka [Development of the Culinary Vocabulary of the Tatar Language of the XX - Early XXI Century]. Filologija i kul'tura, No. 4 (34), pp. 86-91. 
Renne, Elisha 2007. Mass Producing Food Traditions for West Africans Abroad. American Anthropologist, 109 (4), pp. 616-625.

Scott, Elizabeth 2001. Food and Social Relations at Nina Plantation. American Anthropologist, Vol. 103 (3), pp. 671-691.

Stolyarova, Guzel' \& Maddahi, Dzhavad 2012. Izuchenie tadzhikskoj obshchiny v Tatarstane: postanovka problemy [Studying the Tajik community in Tatarstan: posing the problem]. Busyginskie chtenija. Materials of the All-Russian scientificpractical conference, December 21, 2011. Issue 3. Kazan: Yaz, pp. 84-88.

Tatary 1967 = Tatary Srednego Povolzh'ia i Priural'ia [Tatars of the Middle Volga and Urals]. N. I. Vorob'ev \& G. M. Khisamutdinov (eds.). Moscow: Nauka.

Tatary [The Tatars] 2001. Moscow: Nauka.

Traditsionnaya pischa 2001 = Traditsionnaya pischa kak vyrazhnie etnicheskogo samosoznaniya [Traditional Food as an Expression of Ethnic Self-Awareness]. Arutjunov, S. A. (ed.). Moscow: Nauka.

Veselov, Jurij 2015. Sovremennaya sotsialnaya sistema pitaniya [Modern Social Food System]. Bylye gody, No. 1, pp. 68-82.

Veselov, Jurij 2016. Istoriya i sotsiologiya pitaniya [History and Sociology of Nutrition]. Bylye gody, No. 3, pp. 917-926.

Vorobyev 1930 = Vorob’ev, Nikolaj 1930. Materialnaya kultura kazanskikh tatar (opyt etnograficheskogo issledovaniya) [The Material Culture of the Kazan Tatars (The Experience of Ethnographic Research)]. Trudy doma tatarskoi kultury, II. Kazan: Tatpoligraf. 